\title{
"Information and communication technologies support for the participation of universities in innovation networks (comparative study)"
}

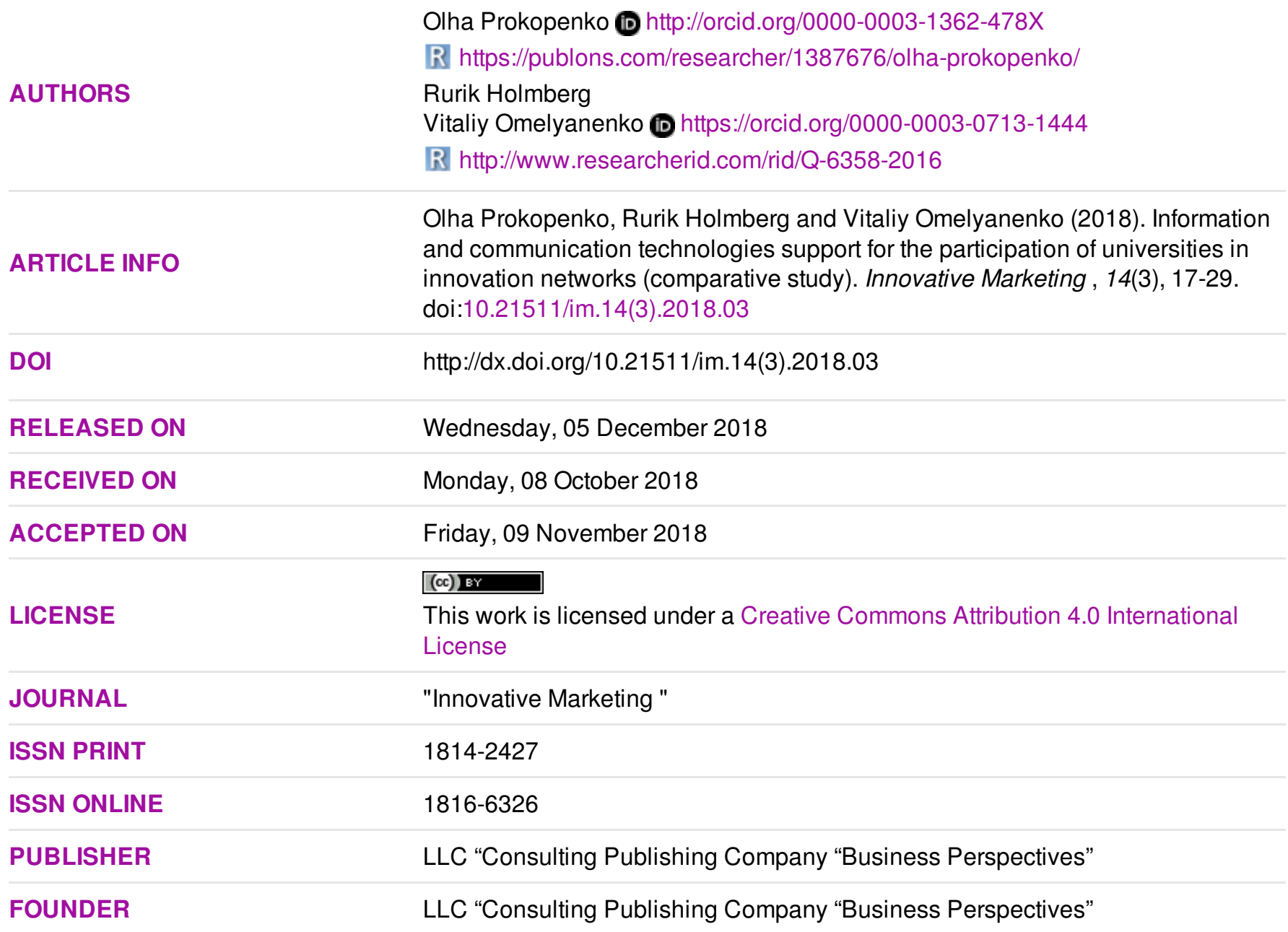

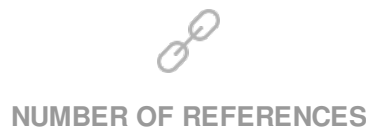

27
NUMBER OF FIGURES

1

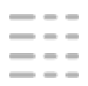

NUMBER OF TABLES

2

(c) The author(s) 2022. This publication is an open access article. 


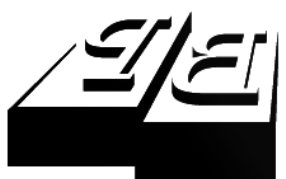

BUSINESS PERSPECTIVES

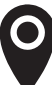

LLC “CPC "Business Perspectives" Hryhorii Skovoroda lane, 10, Sumy, 40022, Ukraine

www.businessperspectives.org

Received on: $8^{\text {th }}$ of October, 2018 Accepted on: $9^{\text {th }}$ of November, 2018

(C) Limited Liability Company "Consulting Publishing Company

"Business Perspectives", 2018

Olha Prokopenko. Doctor of Economics, Professor, University of Bielsko-Biala, Poland; International Humanitarian University, Ukraine.

Rurik Holmberg, Doctor of Technology and Social Change, Linlöping University, Sweden.

Vitaliy Omelyanenko, Ph.D. (Econ.), Associate Professor, Sumy State Pedagogical University named after A.S. Makarenko, Ukraine.

\begin{abstract}
To ensure and strengthen the development of high-tech R\&D and its industrial applications in the long-term perspective, information and communication technologies (ICT) cooperation tools with national and international institutions, network associations and firms are of great importance. To solve this problem, a joint systematic and coordinated work to develop institutions that can provide crucial support to innovation process is crucial. For these purposes, higher educational institutions (HEI) innovation activities information and communication support and technological development analysis are critically important. The purpose of this study is to analyze the existing ICT toolkit, which is used to manage $\mathrm{R} \& \mathrm{D}$ and various industrial applications, and to develop a conceptual framework for the implementation of these tools for the participation of universities in innovation networks. To answer this question, authors begin by taking a closer look at the new role of universities in the development of knowledge generation in a global environment, as well as problems and tendencies under conditions of postindustrial society. The new role of universities in knowledge generation in the global environment development, and problems and tendencies under the conditions of postindustrial society were outlined. Modern ICT components, which are necessary for universities to participate in the innovation networks, were analyzed. Some cases of foreign experience in the scientific and innovation networks of current prototypes of Industry 4.0 development were discussed, and the possibilities of its adaptation to national innovation system formation conditions in Ukraine were identified. By theoretical and empirical examining, the authors propose more complete understanding of modern ICT components, which are necessary for universities to participate in innovation networks. Cases of foreign experience in the scientific and innovation networks of current prototypes of Industry 4.0 development were investigated. Moreover, the evidence from this study suggests a variety of factors related to the possibilities to adapt ICT tools to national innovation system formation in Ukraine.
\end{abstract}

\section{Keywords}

innovation networks, HEI, university, strategy, ICT, innovation activity, cooperation

JEL Classification D83, L86, O32, O57

\section{INTRODUCTION}

Innovations, based on high-tech applications, lead to the creation of new market segments and radical change in existing business models. In turn, the development of high-tech requires research in the framework of international multilateral and bilateral cooperation, including research and education institutions that in the future will determine fundamentally new opportunities for development.

Numerous studies show that higher educational institutions (HEI) can achieve technologically significant academic research results, but at the same time be much less successful in transmitting these results. Cole (2010) estimates that a significant part of the leading industries in the US, perhaps over $80 \%$, originate from discoveries made at American universities. 
In order to ensure and strengthen the development of high-tech $\mathrm{R} \& \mathrm{D}$ and its industrial applications in the long-term perspective, ICT cooperation tools with national and international institutions, network associations and firms are of great importance. To solve this problem, a joint systematic and coordinated work to develop institutions that can provide crucial support to innovation process is crucial. For these purposes, HEI innovation activities information and communication support and technological development analysis are critically important.

\section{THEORETICAL BASIS}

For the purpose of long-term economic growth, new variables, which determine economic growth, need to be understood. In the last decade, several publications have addressed the question and point out ICT as an important source of economic growth and productivity on the supply side. Review of empirical studies, based on panel data, have found that ICT have a positive and significant effect on the growth of developed countries (Hariani, 2017).

Similar ideas can be found in analytical studies of leading international organizations.

For many developing countries, adjusting the innovation resources of digital economy and its potential impact on development prospects is daunting challenge. According to WTO, the impact of the lack of digital and technological capabilities are cementing and widening the technology divide (WTO, 2017).

The combination of three main information and communication technologies of Industry 4.0 (data, internet of things, online sharing platforms) are the cornerstone of the digital revolution, which is already transforming economies and societies by changing the ways people interact, how business functions and innovates and how the government designs and implements policies (OECD, 2017).

According to UNCTAD (2018) technological progress can facilitate institutional changes. Experts of UNCTAD consider advances in ICTs as a facilitation factor of global value chains (GVCs) emergence and global networks formation.

Pradhan, Mallik, and Bagchi (2018), probe the extent of broadband and internet applications. These two innovations have had a remarkable impact on communication and interaction on the con- duct of decision-makers in business and administration (two key drivers of economic prosperity). Jorgenson and $\mathrm{Vu}$ (2016) provide empirical evidence of ICT and its economic impact and highlight policy issues that are deemed important for a country to seize the ICT revolution for promoting economic growth.

UCTAD experts (2018) note that the emerging digital economy is built on digital infrastructure, comprising three closely interrelated components:

1) communication networks;

2) software packages and related capabilities;

3) data platforms.

Over the past two decades, countries have been steadily building their digital communications network around institutions, skills and practices of internet as the principal tool for information flow management.

When describing ICT impact for promoting economic growth in the mentioned publication, relatively small attention for some innovation policy issues is given. So, to make a review of these aspects, especially the innovation networks, can be useful for our study.

Innovation networks reflect current innovation trends of collaborative and open innovations. Freeman (1991) has pointed out that "the problem is not simply to get a lot of information, there is often information overload. The problem of innovation process is to elaborate and to convert information from different sources into useful knowledge about projecting, production and sale of new products and processes".

Todaro (2011) has found that human capital is considered as a very important factor of technological 


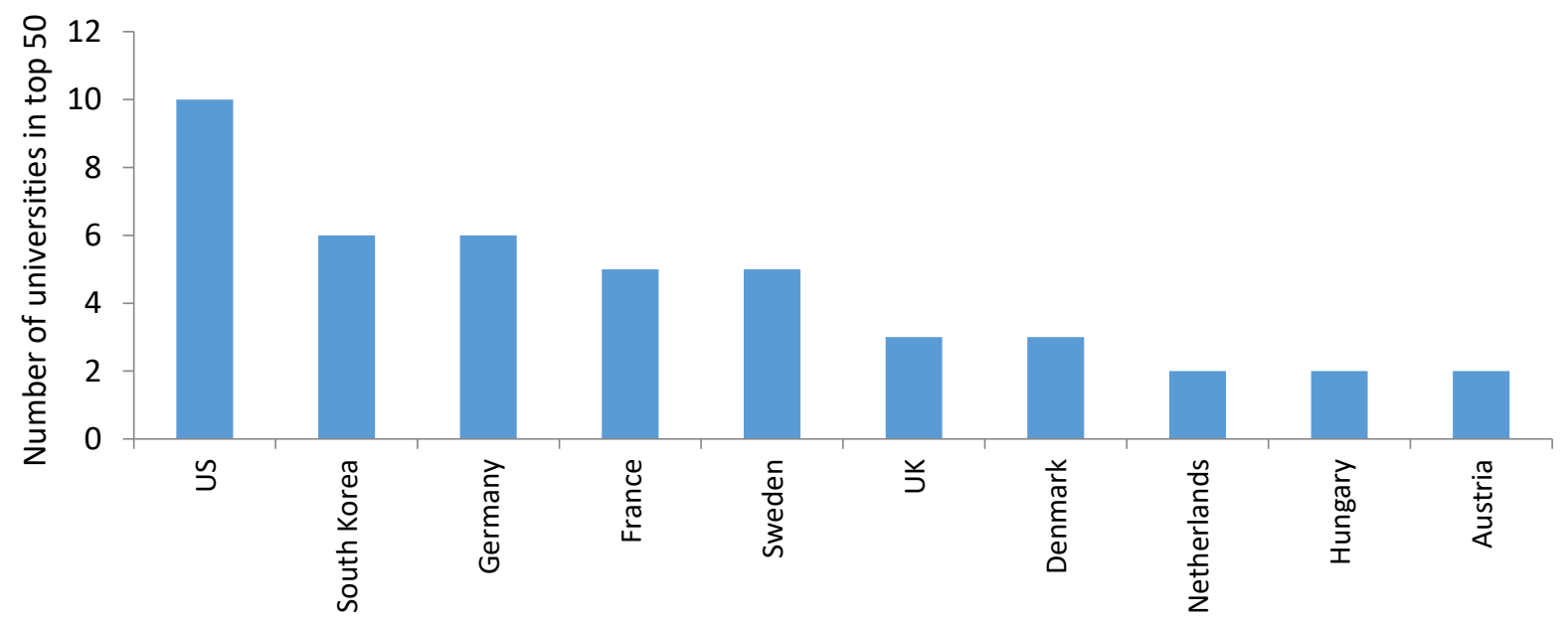

Figure 1. Number of universities in top 50 of world university rankings universities with the most industry collaborations

change, so improving the ability of a humans to innovate can be one ICT policy target. ICT technologies generate on average substantially larger knowledge spillovers than those generated by other technology areas (Draca, Martin, \& SanchisGuarner, 2018).

The key function of innovation networks operators' interaction is to disseminate any information in different forms and methods of its activity or service provision. ICT is the tool of such activities or services provision.

Deloitte experts (Deloitte, 2015) focus their attention on four points: vertical networks, horizontal integration, engineering at all value chain stages (surplus value chain) and all processes fastening implementation of company processes through technology. In this situation, the universities and their role as sources on innovations can be discussed.

Figure 1 and Table 1 are composed based on Times Higher Education Rankings and illustrate data university-corporate partnerships. The fact of inclusion of the indicators of universities-industry collaborations to the Times Higher Education Ranking methodology illustrates the value of this collaborations for universities development.

In these conditions, it is important to emphasize that the role of ICT can be investigated within the interactive model of the innovation process- es. Its central conclusion deals with the fact that close synergetic links between various parts in the $\mathrm{R} \& \mathrm{D}$ system organization, between $\mathrm{R} \& \mathrm{D}$ systems and other production systems, between organization and other private and state institutions are required for successful innovations.

The so-called triple helix, referring to cooperation between institutions of higher education, business and government bodies, has been in focus since the late 1990's. In particular, developments in Sweden in this area have gained significant attention, which might be a consequence of early attempts to create a national structure for a national innovation system.

Klofsten et al. (1999) observed that in the Swedish city of Linköping, high-tech spin-off from the university to business was crucial for Linköping to emerge as one of Europe's fastest growing regions in terms of technological development.

The triple helix approach has been refined by, among others, Ranga and Etzkowitz (2013), whereby the actual processes of knowledge transfer have been placed in the foreground.

Cooperation between academia and business in Sweden is further strengthened by the so-called teacher exemption, by which it is referred to Sweden unique law according to which university employees have the intellectual property rights to inventions they have made as employees (Law, 
Table 1. Most prolific university-corporate partnerships

Source: Morgan (2017).

\begin{tabular}{|c|c|c|c|c|c|c|c|}
\hline Rank & University partner & Country & $\begin{array}{c}\text { Corporate } \\
\text { partner }\end{array}$ & $\begin{array}{l}\text { Corporate } \\
\text { partner's } \\
\text { country }\end{array}$ & $\begin{array}{c}\text { Total } \\
\text { number of } \\
\text { coauthored } \\
\text { papers }\end{array}$ & $\begin{array}{c}\text { Percentage } \\
\text { of corporate } \\
\text { partner's } \\
\text { total output }\end{array}$ & $\begin{array}{c}\text { Percentage } \\
\text { of university } \\
\text { partner's } \\
\text { total output }\end{array}$ \\
\hline 1 & $\begin{array}{l}\text { Norwegian University } \\
\text { of Science and } \\
\text { Technology }\end{array}$ & Norway & SINTEF & Norway & 1,711 & 48.86 & 9.11 \\
\hline 2 & $\begin{array}{l}\text { China University of } \\
\text { Petroleum }\end{array}$ & China & $\begin{array}{l}\text { China } \\
\text { National } \\
\text { Petroleum }\end{array}$ & China & 588 & 23.17 & 5.55 \\
\hline 3 & $\begin{array}{l}\text { Sungkyunkwan } \\
\text { University }\end{array}$ & South Korea & Samsung & South Korea & 980 & 9.63 & 4.95 \\
\hline 4 & $\begin{array}{l}\text { Eindhoven University } \\
\text { of Technology }\end{array}$ & Netherlands & $\begin{array}{l}\text { Philips } \\
\text { Research }\end{array}$ & Netherlands & 562 & 22.78 & 4.06 \\
\hline 5 & $\begin{array}{l}\text { Korea Advanced } \\
\text { Institute of Science and } \\
\text { Technology }\end{array}$ & South Korea & Samsung & South Korea & 734 & 7.21 & 3.55 \\
\hline 6 & $\begin{array}{l}\text { Pohang University } \\
\text { of Science and } \\
\text { Technology }\end{array}$ & South Korea & Samsung & South Korea & 386 & 3.79 & 3.42 \\
\hline 7 & $\begin{array}{l}\text { Gwangju Institute } \\
\text { of Science and } \\
\text { Technology }\end{array}$ & South Korea & Samsung & South Korea & 189 & 1.86 & 3.24 \\
\hline 8 & $\begin{array}{l}\text { China University of } \\
\text { Petroleum }\end{array}$ & China & $\begin{array}{c}\text { China } \\
\text { National } \\
\text { Offshore Oil } \\
\text { Corporation }\end{array}$ & Hong Kong & 325 & 34.50 & 3.07 \\
\hline 9 & $\begin{array}{l}\text { China University of } \\
\text { Petroleum }\end{array}$ & China & Sinopec & China & 303 & 18.36 & 2.86 \\
\hline 10 & Hanyang University & South Korea & Samsung & South Korea & 598 & 5.88 & 2.68 \\
\hline
\end{tabular}

1949, p. 354), which has opened up for the fast dissemination of research. This process has been supported by various types of active "match-making" between universities and business, where the universities have initiated cooperation, as shown by Berggren (2011) in a case study of Chalmers University of Technology in Gothenburg.

In the last decade, many studies have been carried out on both formal networks (such as contract agreements on cooperation in R\&D) and informal networks (e.g., occasional exchange of information between different researchers and/or firms). One may distinguish the following questions and concepts, which are often observed in the literature.

While examining of innovation networks in the previous studies (Prokopenko, Kudrina, \& Omelyanenko, 2018), the role of ICT in universities' innovation activities was analyzed.

Brahimi, Sarirete, and Khalifa (2018) note that universities have moved from a traditional approach, focusing on education, to a next generation of universities, focusing on education and research, and recently to a third generation, focusing on learning, innovation and entrepre- neurship. Within the context of third generation universities, there is a continuous call to support innovation in education and how to deal with the challenge of contemporary engineering design problems.

According to the Association of Universities of Applied Sciences (2018), ICT can help to get more out of efforts in research, for example, by targeting the sharing of research results and networking of researchers. ICT within the innovation networks allow for combining research capacity and areas of attention for effectiveness of educational innovations and ensure research results are translated into and connected to education in practice. The authors point out the learning ability to acquire and share knowledge not only inside as traditional learning theories, but also outside using technology through communications.

So the role of ICT in the context of functional spheres in the university activity, which have to function within the network, i.e. with purpose to receive synergy, can be studied.

Particularly, Benneworth (2009) distinguishes four directions in university activities: 
- "Engaged Research" includes research projects regarding active participation in the country's (or region's) activities, in the construction of a knowledge society, and also researches carried out by order of non-commercial organizations;

- "Knowledge Sharing" - collective use of knowledge comprises consulting, knowledge transfer through consultations for students, publicly funded projects to exchange knowledge, support of public dialogue and work with mass media;

- "Services" presupposes accessibility of university services, expert service provision, work for the sake of society;

- "Teaching" as one of the activity spheres deals with public lectures, seminars, advanced training, and also continuing education and life-long education.

The central question then becomes: how ICT effect on all of these university activities and what directions for the task of ICT strategy development can be observed. Given this evidence, an examination of the factors that impact upon HEIs ICT strategy seems to be warranted.

Laredo (2007) analogically distinguishes eight parameters of university's "third mission". Together with university's participation in society's cultural, public and political life, focus is on knowledge transfer through intellectual property objects, patent activity, creation of entrepreneurial structures, agreements with industrial enterprises and human resources, where knowledge is transferred to graduate students. The evidence from these studies suggests a variety of factors related to ICT applications.

In the context of technology transfer skills training, the authors propose to study ICT that will help to implement innovation communications of universities. So, in the framework of development strategies, the main aspects of digitization can be determined.

Therefore, the purpose of this study is to analyze the existing ICT toolkit, which is used to manage
$\mathrm{R} \& \mathrm{D}$ and industrial applications, and to develop a conceptual framework for the implementation of these tools for the participation of universities in innovation networks.

In order to achieve the research goals, such research objectives were outlined:

to outline the new role of universities in knowledge generation in the global environment development, and problems and tendencies under the conditions of postindustrial society;

to analyze modern ICT components, which are necessary for universities to participate in the innovation networks;

to discuss some cases of foreign experience in the scientific and innovation networks of current prototypes development of Industry 4.0, and to identify the possibilities of its adaptation to national innovation system formation conditions in Ukraine.

Our research is based on the synergetic theory of information and its application for R\&D and industrial network applications specifics within Industry 4.0. Within the framework of this theory, two parallel processes can be examined:

1) constant increase of the role and amount of information necessary for $\mathrm{R} \& \mathrm{D}$ and industrial applications development; and

2) improvement of technology for information accumulation and dissemination.

The main idea of this study is based on the understanding that new technologies can be considered as one of the most promising technological direction capable of creating the necessary conditions for the development of the next generation of consumer technologies with cloud technologies (e.g., PaaS model) and collaborative software (created to support interaction between people working together to solve some common problems), and applications for devices.

So the range of the digitalization of innovation networks and technology transfer problems in the context of Industry 4.0 formation is aimed at 
the integrated development of universities' ICT based innovation ecosystem, their synchronization with other innovation infrastructure objects, cooperation development with high-tech business, applied research implementation and intellectual activity results commercialization.

It was underlined that the ongoing fourth industrial revolution encourages everyone to adapt faster and therefore a situation when success is achieved by those companies that work closely with universities and startup centers and introduce modern technologies in production is clearly visible.

In order to solve the tasks for the research, both classical scientific methods (analysis and synthesis, logical generalization, analogies, comparative analytics) and specific methods of the economy of high-tech and innovative management are used.

The following methods are used to determine the objectives of ICT in innovation communications within the universities:

- adapted decision-making methods based on optimization of performance indicators (which are used to investigate the innovation role of universities);

- methods based on the analysis of schemes for the strategic development of innovation systems and intersectoral high-tech complexes (which are used to develop the main points of ICT application for universities' strategy);

- methods of searching for innovative ways for development and methods of integrated economic analysis of development policy (are used to develop the innovation partnership strategies of HEIs).

The fundamental principles of strategical management of institutional dynamics within the framework of development strategies require constant research, as currently the situation in the innovation sphere is constantly changing. This requires focus on identifying pressing problems and determining the prospects of how ICT can help under conditions of technological changes.

\section{RESULTS}

It is very clear from given observations that nowadays innovation networks are actively involved in modern business processes, proposing effective ways for complex projects realization. Number of multiservice networks, which propose functions of high accessibility, security, service and management quality control, is growing. The business sphere and governments have many tasks related to network infrastructure and ICT introduction, because digital transformation lead to either some problems (loss of development resources) or some opportunities (formation of synergy). That is why government offices at the national, state or local level facing citizens' growing expectations have to provide complex and extended services.

Digitalization and ICT propose new platforms and applications for interactions, sorted and integrated processes, and informational technologies for various analytics. Besides, international R\&D cooperation, which has become more effective thanks to modern communication media, has decisive value in solving complex problems, internal and international security, etc. Therefore, innovation communication, collaborative tools and cloud services form new abilities to coordinate efforts and to prevent future problems.

One of the most striking features of this problem is that under such conditions, while realizing new tasks, the education (especially higher education) sector has to achieve great progress in digitization and leading ICT sphere to compensate for lost positions.

In this context, one can confirm that individual decisions in the ICT sphere, modern network infrastructure and cloud decisions will play main role in universities development. ICT is a key to re-engineering and the rationalization of education processes. In this case, it will have fundamental importance for future efforts regarding higher education system modernization, especially technology transfer tasks (including social ones). Thus, digital transformation of the higher education system is most essential - and, really, it is advisable to cope with future challenges and to keep competitiveness in the globalization and Industry 4.0.

The role of networks is essentially growing, be- 
cause future education will cut distance between employer and employee, and therefore the educational service market will increase its flexibility and degree of self-stabilization.

As a result, ICT in the innovation and educational networks will participate in such aspects:

- large corporations will be able to "order" definite professions and competences, including those within the framework of project approach (education via real $R \& D$ projects) without government mediation;

- organizations, which demand collective intellect and team formation, can enter the educational market and propose specialized courses;

- carriers of new interactive educational technologies will be able to be united into professional associations and to form "university associations" with their standards and teaching methods. In the course of time, these structures may provide competition to traditional universities, maybe even drive them from educational service market after 25-30 years;

- in order to realize the model of future education, a developed high technological infrastructure is required, operatively renewable bases will be formed on the ground of BigData technologies;

- in the course of time, stock exchange of cooperative and individual study education abilities, platforms-shops of the educational content are appearing;

- mass assessment tests to define general education level will gradually become irrelevant. They will be replaced by Internet systems of evaluation and certification, enabling to receive external confirmed evaluation about certain competences and skills.

In modern conditions, HEIs have new peculiarity, i.e. inclusion to the regional development tasks. In a number of countries, universities' responsibility for social development is designated. It is so called universities" "third mission", besides science and education, - responsibility for cooperation with local associations for development.

The role of ICT should be analyzed from the point of innovation communications. In Ukraine, the following problems prevent from transfer to the innovation model of development:

companies and enterprises are not enough informed about new technologies and possibilities to access to them with the help of innovation infrastructure elements;

- mechanisms to stimulate companies and enterprises to develop technological cooperation and to use innovations are underdeveloped;

- scientific potential is weakly involved into economy owing to absence of the technologies transfer networks and platforms;

innovation infrastructure is fragmentary and is not digitized, relations between organizations of innovation infrastructure are underdeveloped (exchange of experience, methodology, best practice);

- systematic mechanism of innovation infrastructure services financial support for company and scientific organizations is underdeveloped. The best practice (native and international) of support and innovation infrastructure development is weakly used.

In order to solve these problems, it is necessary to develop infrastructure of innovation development support, one element of which is ICT technologies transfer infrastructure.

Against this background, the central question that motivates this paper is that the technologies transfer assistance in the context of "third mission" includes not only services, directly related to transfer and commercialization of production technologies in a strict sense, but also social technologies and related services (education, intellectual property protection, marketing research, etc.).

Besides the solving of main task - to assist technological cooperation between organizations of scientific and educational sphere, companies and 
enterprises, it will allow to carry out concrete actions regarding realization of the innovation development policy.

There are many terms, which mean different types of organization network interaction in the innovation activity. More general interpretation in the modern literature (Titov, 2009) states that innovation network consists of innovation, providing, financing and commercialization subsystems.

IT solutions play a key role in the work of innovation and providing subsystems.

Generally, innovation subsystem includes organizations, carrying out innovation activity on development and production of innovation and intellectual products (with optimal use of their resources).

Providing the subsystem unites the objects, which directly do not take part in creation and production of innovations, but play a significant role to provide this process, this subsystem consists of 3 parts:

1) scientific and technical provision - organizations, which function at the market of technologies, informational resources and service;

2) provision of the innovation network production system with raw materials resources;

3) provision of the internal communication between all agents of the innovation network, creation and service support of data collection vehicle.

\section{DISCUSSION}

Identified innovation network tasks and its ICT component, which is responsible for communications, include:

- to assist scientific organizations, companies and enterprises of the region to find technological collaboration partners, to set contacts, to hold negotiations, to conclude agreements;

- to reveal technological needs and investigations in scientific organizations, enterprises and companies of the region, to help to form technological requests and proposals;

- to form databases;

to help scientific organizations, companies and enterprises of the region to prepare technological investigations to selling, to prepare commercialization projects;

- to carry out marketing researches of technological market;

- to train and to give expert support for the innovation process participants (representatives from scientific organizations, companies of small and medium-sized business, industrial enterprises, innovation centers, administrations) in the sphere of methods to use modern tools for technologies transfer, and issues regarding intellectual property and innovation business dealing methods;

- to develop workforce capacity for innovation activity. Involvement of students and postgraduates, studying on technical specialties, to work in the technologies transfer sphere;

- to give consulting and expert support for users of the technologies transfer regional system.

Based on the research of Gordenko (2011), the following types of innovation networks related to universities, which makes possible selection an appropriate ICT component, can be analyzed (Table 2).

An important step on digitization is to find technological decisions to realize above tendencies while forming educational programs, to change over to the new model of scientific and educational process and to support the whole lifecycle of scientific and educational production. In the near future, those HEIs will be competitive, which will be able to use ideas, included to the conception Industry 4.0 , to individualize course of graduates' training in the format of life-long learning.

Implementation of modern ICT to control educational process is directly related to change over to project and process model of HEI governing. In order to answer the question of wider ICT capacity, let's 
Table 2. Types of innovation networks

\begin{tabular}{|c|c|}
\hline Type & Description \\
\hline $\begin{array}{l}\text { Cooperation network in the R\&D } \\
\text { sphere }\end{array}$ & $\begin{array}{l}\text { Research groups, cooperating to carry out complex research projects (focus is on new } \\
\text { knowledge generation) }\end{array}$ \\
\hline Technologies transfer network & $\begin{array}{l}\text { Stable partnership links between scientific and production teams, providing fast } \\
\text { commercialization of the research results (focus is on new knowledge commercialization) }\end{array}$ \\
\hline Educational service network & Promotion of innovation education programs \\
\hline $\begin{array}{l}\text { Special competences transfer } \\
\text { network (education network) }\end{array}$ & $\begin{array}{l}\text { Actively interacting expert society, the aim of which is to expand competencies regarding } \\
\text { key questions of science owing to synergy effect (focus is on new knowledge generation) }\end{array}$ \\
\hline Services network & $\begin{array}{l}\text { Scientific, educational and industrial organizations - partners, united by the only one goal } \\
\text { (focus is on the support service) }\end{array}$ \\
\hline Scientific and innovation networks & $\begin{array}{l}\text { Scientific, educational and industrial organizations - partners, united by the only one goal } \\
\text { (focus is on innovation cycle management) }\end{array}$ \\
\hline $\begin{array}{l}\text { Expert and consulting support } \\
\text { networks }\end{array}$ & $\begin{array}{l}\text { Scientific, educational and industrial organizations - partners, united by the only one goal } \\
\text { (focus is on the expert or consulting support) }\end{array}$ \\
\hline $\begin{array}{l}\text { Internal network of university } \\
\text { governing }\end{array}$ & Internal cooperation orient on business-processes coordination \\
\hline
\end{tabular}

take a closer look at information and technological support of the customer-oriented approach to form educational programs and to create smart environment at HEI that can be realized based on such tools:

- animation use, based on Flash technology, mobile applications and media services investigation;

- educational engineering and global network technologies;

- knowledge management and LMS (learning management system);

- intelligent DSS;

- business intelligence;

- managing changes in business re-engineering;

- CRM systems;

- cognitive analysis and modeling of situations in the weakly structured objects and spaces management.

New education and innovation models are based not only on some tools. The main idea is to be able to build new business models, based on specialized technologies. Empirical analysis of some cases can produce a more complete understanding of HEI ICT-based strategies.

Firstly let's describe the practice of ESB Business School at Reutlingen University (ESB Business
School at Reutlingen University, 2018) in Germany, which has to face with the same difficulties in the curriculum formation as in technological processes organization.

Future Master Degree graduates work on projects in the specially constructed ESB Learning Factory, which combines physical infrastructure for production with cloud tools of digital projecting, twice a week during 4 months. They learn how to treat with big data, digital processes, new business models and new principles of cooperation between departments. That is why, in this case, it can useful to try to create ESB Learning Factory, oriented toward future needs, which will let students to receive practical skills in using of up-to-date technology in the context of Industry 4.0.

Second example is National Engineering School of Metz (France), included to Lorraine-INP, collegium of 11 technical schools of University of Lorraine. ENIM started the program Factory Futures, international co-project, based on implementation of cloud technologies to manage production life cycle (PLM), in order to teach students from the whole world to work at "factory futures" (Factory Futures, 2018).

Teaching model at technical schools in France and abroad does not presuppose to include to the curriculum a lesson on our youth training to realize technical projects in the global context. The obligatory condition for ENIM students is mobility. Over 120 agreements with institutes in different parts of the world have been already signed. 
The project Global Factory, started in 2012 together with program Factory Futures, started in September 2016, gives an opportunity to students to carry out technical project with participation of 17 universities-partners, working with hundreds of students and professors in 10 countries. An additional aim was experience exchange to master digital 3D-decisions in the PLM sphere with HEIs-partners.

Next example is Festo (Festo, 2018), where students are taught on special training equipment. Particularly, learning factory has successfully functioned in Germany at new plant Festo. It is maximum convergence of scientific investigations, innovation training equipment and real production. All ideas, successfully tested at this factory, are quickly introduced into the real production. Besides, Festo developed special training equipment - CP labs or cyber physical laboratories. In fact, they are mini-plants, built due to the modern principles. They are module and are easily adapted to changes. Modules communicate with each other by network protocols, data are hold in the cloud, system ERP is connected to this production.

The teaching programs are arranged in such a way that participants will be able not only for example to draw a scheme on the table or to write a program on computer, but also to see how this program works under industrial conditions. When trainings are finished, where pneumatic and hydro schemes are reviewed, participants set up schemes of diverse complexity. Moreover, they can find defects and learn how to extract them. Today this skill is very popular. When talking about trainings for programmers, they not only write programs for controllers, operator panels, SCADA systems, but also set and check their work on real equipment.

Let us distinguish Indian experience, production share of which was $16 \%$ of GDP according to data of World Bank in 2014. That same year, Prime Minister of India Narendra Modi launched the initiative "Make in India" in order to involve foreign investors and to turn India into global production center.

That is why technical specialists were required who possess skills in several disciplines at once in order successfully to compete at the global level, and another approach to study is necessary for it. This approach was practically realized at Technological University KLE. Here students are taught how to work with technologies, showing the factory of future, including big data, clouds, analytics, integrated systems, robotics industry and automatization, but there is no complex approach to their teaching.

Factory Futures is an environment for team work, where many processes may flow at once in different physical places, and probably intercultural problems appearing. It is important to create such education environment, which renders the situation in production that students may feel ties with future working place.

That is why education schedule at KLE Tech is composed with focus on practical study. Social innovations are taught for the first-year students. Future investigators' thinking is set for social needs. Many technical disciplines also are taught in order to stimulate extended production thinking. In future, interdisciplinary approach to realize lifecycle of production at university's learning factory with area 557 sq. meters is suggested for students.

Students work in the interdisciplinary groups to which future machine builders and engineers-electrical technicians get in order to make them to imagine how different working groups with joint efforts achieve common aim. In order to teach these skills, teaching staff of KLE Tech had to expand knowledge beyond main specialization.

Problems in the current training system were defined together with representatives of production sector. Although students have to work in interdisciplinary groups, at first, it is necessary to test it, lecturers gained proper experience before lessons.

Great attention should be paid to global leaders who actively introduce new approaches and compete with traditional educational institutions.

Intel realizes its strategy in three directions:

- IT go forward to organize educational process: digital content with materials on lessons, tasks, electronic libraries, videoconferences systems are created; 
- IT are used as tools for research and scientific work. The example is development of high productive calculations, which are widely implemented in the research;

- IT are introduced into the sphere of humanities education and sciences, help to create, spread and modify digital content (marketing, PR).

Microsoft has opened 11 centers of innovations in eight cities on the basis of HEIs. They are structures, the main goal of which is cooperation between higher school, industry and state organizations in the sphere of research, technologies and software development. Besides, in our country, the program Microsoft IT Academy is progressing, which is oriented to train IT specialists. Its participants receive study guides, e-learning courses, necessary software and consulting support.

Epson attracts them to cooperate with educational institutions in different directions, starting from projector and screen installation and finishing with introduction of IT system complex project.

Let us point out innovation architecture of digital networks Cisco Digital Network Architecture (Cisco DNA), which is used in agricultural industry as a native decision, which is able to form new bases of education.

Cisco DNA is an open architecture for modern digital enterprise. It combines both current decisions of Cisco and technologies, which have not been used earlier in the corporative segment (e.g., SDN and NFV). Cisco DNA determines and describes recommended interaction for all products and decisions, used within the framework of architecture with the help of software interfaces API.

Besides, Cisco DNA unites those decisions into logical blocks, which close tasks of modern digital enterprise: simplification and automatization of IT processes, fastening of innovations introduction, receiving of complex analytics about the network, applications and users, reducing of cost risks and finally an effective and automatized interaction with main business. Let us mention that this decision has great potential in the educational environment.

From these facts, one may conclude that necessity to realize the ICT support for innovation networks development and universities operation in it is caused by problems of interaction between modern university and society, particularly by low level of cooperation between HEI and social sphere through technologies transfer system.

\section{CONCLUSION}

Analysis of some studiers and some successful cases confirms the idea that some practical aspects of partnership relations society-university are not enough developed. The evidence from these cases suggests a variety of factors and ways related to HEI in innovation networks operation. The arguments given above prove that it is caused by the following factors: weak orientation of HEI to territory development task; absence of interaction experience with labor market, involvement of staff members customer and business to form personnel order, to produce professional standards, and criteria to assess quality of students' training; weak connection of admission structure to HEI with perspectives of regional labor markets development; high degree of disintegration of science, education and business, as a result of which scientific investigations and personnel training are not connected with the economic realities and regional development needs.

All of this points to the fact that modern successful university is not simply as "incubator" to train professional staff members, but as a constant production locality, reproduction and transmitting of knowledge into different regional associations. Thus, our thesis is that there are a number of HEI activity areas, which can be based on ICT, including:

- creation of educational programs, based on the one scientific and educational and innovation process using interdisciplinary problem- and project-oriented educational technologies; 
- organizational structure and project methods of university governing, which are adequate to new tasks, are developed;

- financing resources of university and effective system of fundraising are diversified;

- number of agreements on cooperation and scientific and educational service is increased;

- infrastructure of cooperation between university and external environment, which includes regional, national and international levels, is developed.

- In conclusion, suggestion is made as to how to maintain network activities of universities. In these conditions, such ICT tools can be implemented within the universities participation in innovation networks:

- digital competencies centers and stimulation of applied research and development within the education process and $\mathrm{E} 2 \mathrm{~B}$ cooperation;

- high-speed and reliable data transmission networks for educational and analytical purposes;

- pilot digital factories to popularize the digitalization process across the entire spectrum of HEI specialties;

- raising awareness in the business environment of new opportunities and the need for cooperation with HEIs;

- new types of network technology transfer tools based on the smart production with its combination with education ("R\&D + EdTech" model);

- $\quad$ specialized sectoral communication platforms with business.

Clearly, some of propositions that we have offered are not entirely unique, but our study enhances academic understanding of the ICT capacity for HEI within the global innovation networked economy development.

\section{ACKNOWLEDGMENT}

The publication was publicly funded by Ministry of Education and Science of Ukraine for developing of research project No. 0117U003855 "Institutional and technological design of innovation networks for Ukraine national security systemic providing" and contains the results of studies conducted by President's of Ukraine grant for competitive project No. 0118U005233 "Formation mechanisms of strategic management in national security of Ukraine area based on innovation system systemic stability" of State Fund for Fundamental Research.

\section{REFERENCES}

1. Association of Universities of Applied Sciences (2018). Acceleration Plan Educational Innovation with ICT Association of Universities.
2. Benneworth, P., Charles, D. Conway, C., \& Younger, P. (2009). Characterizing Modes of University Engagement with Wider Society: A literature review and survey of best practice (Final report). Newcastle: Office of the Pro-Vice-Chancellor (Engagement), Newcastle University, UK. 
3. Berggren, E. (2011). The entrepreneurial university's influence on commercialization of academic research - the illustrative case of Chalmers University of Technology. International Journal of Entrepreneurship and Small Business, 12(4). https://doi. org/10.1504/IJESB.2011.039684

4. Brahimi, T., Sarirete, A., \& Khalifa, S. (2018). Impact of Accreditation on Engineering Education. In M. Lytras, L. Daniela \& A. Visvizi (Eds.), Enhancing Knowledge Discovery and Innovation in the Digital Era (pp. 91-106). Hershey, PA: IGI Global. https://doi. org/10.4018/978-1-5225-4191-2. ch005

5. Cole, J. R. (2010). The great American university: Its rise to preeminence, its indispensable nation role, why it must be protected. N. Y.: Public Affairs.

6. Deloitte (2015). Industry 4.0. Challenges and Solutions for the Digital Transformation and Use of Exponential Technologies. Retrieved from https://www2.deloitte.com/content/dam/Deloitte/ ch/Documents/manufacturing/ ch-en-manufacturing-industry-4-0-24102014.pdf

7. Draca, M., Martin, R., \& SanchisGuarner, R. (2018). The Evolving Role of ICT in the Economy (A Report by LSE Consulting for Huawei). London School of Economics and Political Science.

8. ESB Business School at Reutlingen University (2018). Retrieved from https://www.esb-business-school. de/en/homepage/

9. Factory Futures (2018). Retrieved from http://factory-futures.univlorraine.fr

10. Ferraro, G., \& Iovanella, A. (2017). Technology transfer in innovation networks: An empirical study of the Enterprise Europe Network. International Journal of Engineering Business Management, 9, 1-14. https://doi. org/10.1177/1847979017735748

11. Festo (2018). The Cyber-Physical Factory. Retrieved from https:// www.festo-didactic.com/int-en/ highlights/qualification-for-industry-4.0/cyber-physical-factory/
12. Gordenko, G. V. (2011). [Перспективы развития инновационных сетей] [Perspektivy razvitiya innovatsionnykh setey]. Retrieved from https://innclub.info/ wp-content/uploads/2011/02/ горденко_6_конк_дд.doc

13. Hariani, P. (2017). Impact of Icts Development on Economic Growth in Indonesia. IOSR Journal of Economics and Finance (IOSR-JEF), 8(5), Ver. III, 49-56. Retrieved from http://www.iosrjournals.org/iosr-jef/papers/Vol8Issue5/Version-3/G0805034956. pdf

14. Jorgenson, D. W., \& Vu, K. M. (2016). The ICT revolution, world economic growth, and policy issues. Telecommunications Policy, 40(5), 383-397. https://doi. org/10.1016/j.telpol.2016.01.002

15. Klofsten, M., Jones-Evans, D., \& Schärberg, C. (1999). Growing the Linköping technopole - a longitudinal study of triple helix development. The Journal of Technology Transfer, 24(2-3), 125-138.

16. Laredo, Ph. (2007). Main Transformations, Challenges and Emerging Patterns in Higher Education Systems. Paper presented at UNESCO Research Seminar for the Regional Scientific Committee for Europe and North America. Retrieved from http://unesdoc.unesco.org/ images/0015/001504/150429e.pdf

17. Marekha, I., \& Omelyanenko, V. (2017). Cultural aspect of innovation strategies' ecologization. Economic AnnalsXXI, 162(11-12), 9-12. https://doi. org/10.21003/ea.V162-02

18. Morgan, T. (2017). Universities with the biggest corporate links. Retrieved from https://www. timeshighereducation.com/features/universities-with-biggestcorporate-links

19. OECD (2017). Digital Economy Outlook 2017. Paris: OECD Publishing.

20. OECD (2018). Transformative Technologies and Jobs of the Future (Background report for the Canadian G7 Innovation Ministers' Meeting Montreal, Canada 27-28 March 2018).

21. Pradhan, R. P., Mallik, G., \& Bagchi, P. T. (2018). Information communication technology (ICT) infrastructure and economic growth: A causality evinced by cross-country panel data. IIMB Management Review, 30(1), 91103. https://doi.org/10.1016/j. iimb.2018.01.001

22. Ranga, M., \& Etzkowitz, H. (2013). Triple Helix system: an analytical framework for innovation policy and practice in the Knowledge Society. Industry and Higher Education, 27(3), 237-262. https:// doi.org/10.5367/ihe.2013.0165

23. Titov, L. Yu. (2009). Principles of formation of innovation networks in the real sector of the economy. Problems of Modern Economy, 1(29).

24. Todaro, M. P., \& Smith, S. C. (2011). Ekonomi Pembangunan: Proses, Masalah dan Dasar Kebijakan (11th ed.). Erlangga: Jakarta.

25. UNCTAD (2017). Information Economy Report 2017: Digitalization, Trade and Development. Retrieved from https://unctad.org/en/PublicationsLibrary/ier2017_en.pdf

26. UNCTAD (2018). South South Digital Cooperation for Industrialization: A Regional Integration Agenda. UNCTAD/ GDS/ECIDC/2018/1. Retrieved from https://unctad.org/en/PublicationsLibrary/gdsecidc2018d1_ en.pdf

27. WTO (2017). Report on Panel Discussion on Digital Industrial Policy and Development. Communication from the Africa Group. 